\title{
Histopathological Examination of Patients Operated on for a Neck Mass: 4-Year Follow-Up Results
}

\section{Boyunda Kitle Nedeniyle Opere Edilen Hastaların Histopatolojik İncelemesi: 4 Yıllık Takip Sonuçlarımız}

\author{
Mahmut ÖZKIRIŞ, Mehtap KALA
}

Department of Ear, Nose and Throat, Special Tekden Hospital, KAYSERI, TURKEY

\section{ABSTRACT}

Objective: To investigate the diagnostic distribution of neck masses treated surgically at our clinic and also to discuss the clinical presentation and histological finding of these pathologies.

Material and Method: We retrospectively reviewed the records (age, sex, clinical presentation and histological findings) of 201 patients who presented at our clinic with neck masses between 2006 and 2010 .

Results: Of the 201 patients, 98 (48.75\%) were classified as inflammatory masses, $67(33.33 \%)$ as neoplastic neck masses, and 36 (17.91\%) as congenital neck masses. The mean age was $27.2 \pm 17.2$ in patients with inflammatory neck masses and $11.4 \pm 4.6$ for congenital neck masses. In the neoplastic neck masses group, the mean age was $37.4 \pm 11.6$ for benign lesions but $49.4 \pm 20.6$ in malignant lesions.

Conclusion: When a neck mass is seen, neoplasms should be considered in older adults and inflammatory and congenital masses in children and young patients. Although the history, medical examination and additional diagnostic methods provide important information, the exact diagnosis may only be obtained by histopathological examination.

Key Words: Neck masses, Pathology, Operative surgical procedure

\section{Öz}

Amaç: Kliniğimizde, boyunda kitle nedeniyle takip edilmiş ve cerrahi uygulanmış olan hastaların tanısal dağılımını saptamak, ayrıca bu olguların klinik ve histopatolojik özelliklerini tartışmak.

Gereç ve Yöntem: Kulak Burun Boğaz kliniğimizde, 2006-2010 yılları arasında boyun kitlesi nedeniyle takip edilmiş, tanı ve tedavi amaciyla cerrahi uygulanmış 201 olgunun (107 erkek, 94 kadın) dosyaları yaş, cinsiyet, klinik ve histopatolojik bulguları not edilerek retrospektif olarak incelendi.

Bulgular: Boyun kitlelerinin 98'i $(\% 48,75)$ enflamatuvar, 67'si $(\% 33,33)$ neoplastik, 36's1 $(\% 17,91)$ konjenital orijinli idi. Neoplastik kitlelerin 44'ü $(\% 65,67)$ benign, 23'ü $(\% 34,32)$ malign karakterde idi. Yaş ortalaması enflamatuar kitlelerde 27,2 $\pm 17,2$, konjenital kitlelerde ise $11,4 \pm 4,6$ idi. Benign kitleli hastalarda yaş ortalaması $37,4 \pm 11,6$ iken malign kitleli hastalarda yaş ortalaması 49,4 $\pm 20,6$ idi.

Sonuç: Boyunda kitle ile karşılaşıldığında, ileri yaşlardaki hastalarda neoplazmları, çocuk ve genç hastalarda ise enflamatuvar ve konjenital kitleleri düşünmek gerekmektedir. Anamnez, fizik muayene ve yardımcı tanı yöntemleri önemli bilgiler verse de kesin tanı elde edilen parçanın histopatolojik incelemesiyle konulabilecektir.

Anahtar Sözcükler: Boyun kitlesi, Patoloji, Cerrahi tedavi

\section{INTRODUCTION}

Neck masses are a problem encountered by all physicians and especially Ear Nose Throat specialists. A neck mass can be defined as any abnormal growth or development from the skull base to the level of the clavicula (1). The approach to neck masses is particularly important as the neck contains $35-50 \%$ of all lymph nodes in its lymphatic chain together with many vital organs $(2,3)$. Causes of a neck mass are generally classified as inflammatory, neoplastic and congenital (2). There are many different factors that may

Received : 19.01.2011

Accepted : 05.04.2011 play a role in the etiology of lesions that create a swelling in the neck and lesions in this region therefore require a careful differential diagnosis process. A detailed history and physical examination are essential. We present our retrospective evaluation of neck masses that had undergone diagnosis and treatment at our clinic in the last four years.

\section{MATERIAL and METHOD}

The study population included 201 cases who had presented at our Ear Nose Throat clinic between 2006 and 2010 and were diagnosed histopathologically with excisional

Correspondence: Mahmut ÖZKIRIŞ

Department of Pathology, Special Tekden Hospital, KAYSERİ, TURKEY

E-mail: dramahmut@yahoo.com Phone: +90 5057465238 
and incisional biopsy. We obtained the patient's history, physical examination, laboratory and imaging results, treatment used, histopathological diagnosis and follow-up duration from patient files. All 201 cases had a detailed diagnosis and physical examination and one or more of the diagnostic imaging methods of ultrasonography, computed tomography (CT) or magnetic resonance imaging (MR). Excisional or incisional biopsy under local or general anesthesia had been used for the diagnosis in all cases. Patients thought to have an infectious etiology were administered antibiotic treatment for 15 days and an excisional biopsy performed afterwards if there was no clinical improvement. Patients whose diagnosis had been made with non-surgical methods (such as fine needle aspiration biopsy) or who were metastatic and the primary was not in the neck were excluded from the study. The tissue samples of all patients who had undergone excisional or incisional biopsy were evaluated at the pathology laboratory. The statistical analysis of our study was with the SPSS 10.0 package software.

\section{RESULTS}

The male/female distribution was 107 to 94 and the age range was 5-74 (mean age 37.4). The definite diagnosis of the cases was with histopathological investigation. The histopathological diagnosis of the neck masses were inflammatory in 98 (48.75\%), congenital in $36(17.91 \%)$ and neoplastic in 67 (33.33\%) (Figure 1-4). Reactive lymphoid hyperplasia was the most common inflammatory lesion [47 cases (47.95\%)] and a thyroglossal duct cyst was the most common congenital mass [18 cases (50\%)]. Neoplastic masses were malignant in $23(34.32 \%)$ and benign in 44 (65.67\%) cases. The most common malignant neoplastic mass was a lymphoma [10 cases (43.47\%)], and the most common benign neoplastic mass was a lipoma [16 cases $(36.36 \%)]$. The mean age was $27.2 \pm 17.2$ for inflammatory masses and $11.4 \pm 4.6$ for congenital masses. Patients with a benign neoplastic mass had a mean age of $37.4 \pm 11.6$ while those with a malignant neoplastic mass had a mean age of $49.4 \pm 20.6$ (Table I).

\section{DISCUSSION}

A neck mass is frequently encountered in ear nose throat practice and can be seen at any age group. Many factors play a role in the etiology of neck masses but inflammatory, neoplastic, congenital and traumatic causes should be especially considered in the differential diagnosis $(2,3)$. A systematic diagnostic approach is essential with so many etiological factors. The first diagnostic step for the patient presenting with a neck mass is a good history and physical examination. Radiological evaluation frequently provides guidance but the definite diagnosis in these patients is usually only made by the histopathological investigation of the surgically excised tissue samples (1-3).

One of the first features to consider in patient presenting with a neck mass is the age (4). Inflammatory and congenital causes are common in the etiology of neck masses in children and adolescents (5). A malignancy must be ruled out in adults who drink and smoke. Factors that increase the risk of neoplastic disease must be queried. The presence of

Table I: Distribution of neck masses of inflammatory, congenital and neoplastic origin

\begin{tabular}{|l|c|}
\hline Inflammatory Masses & $98(48.75 \%)$ \\
\hline Reactive lymph node hyperplasia & 47 \\
\hline Tuberculosis & 28 \\
\hline Chronic Sialoadenitis & 18 \\
\hline Castleman's Disease & 2 \\
\hline Sarcoidosis & 1 \\
\hline Kikuchi's Disease & 1 \\
\hline Cat Scratch Disease & 1 \\
\hline Congenital Cysts & $36(17.91 \%)$ \\
\hline Thyroglossal Duct Cyst & 18 \\
\hline Epidermal Cyst & 10 \\
\hline Brachial Cyst & 4 \\
\hline Dermoid Cyst & 3 \\
\hline Hemangioma & 1 \\
\hline Neoplastic Masses & $67(33.33 \%)$ \\
\hline A. Maligant neoplastic masses & 23 \\
\hline Lymphoma & 10 \\
\hline Squamous Cell Carcinoma & 8 \\
\hline Mucoepidermoid Carcinoma & 3 \\
\hline Renal Cell Carcinoma Metastasis & 1 \\
\hline Adenocarcinoma & 1 \\
\hline B. Benign neoplastic masses & 44 \\
\hline Lipoma & 16 \\
\hline Pleomorphic Adenoma & 14 \\
\hline Monomorphic Adenoma & 5 \\
\hline Warthin Tumor & $\mathbf{2 0 1}(\mathbf{1 0 0 \% )}$ \\
\hline Paraganglioma & \\
\hline Schwannoma & 6 \\
\hline TOTAL & 1 \\
\hline & \\
\hline
\end{tabular}




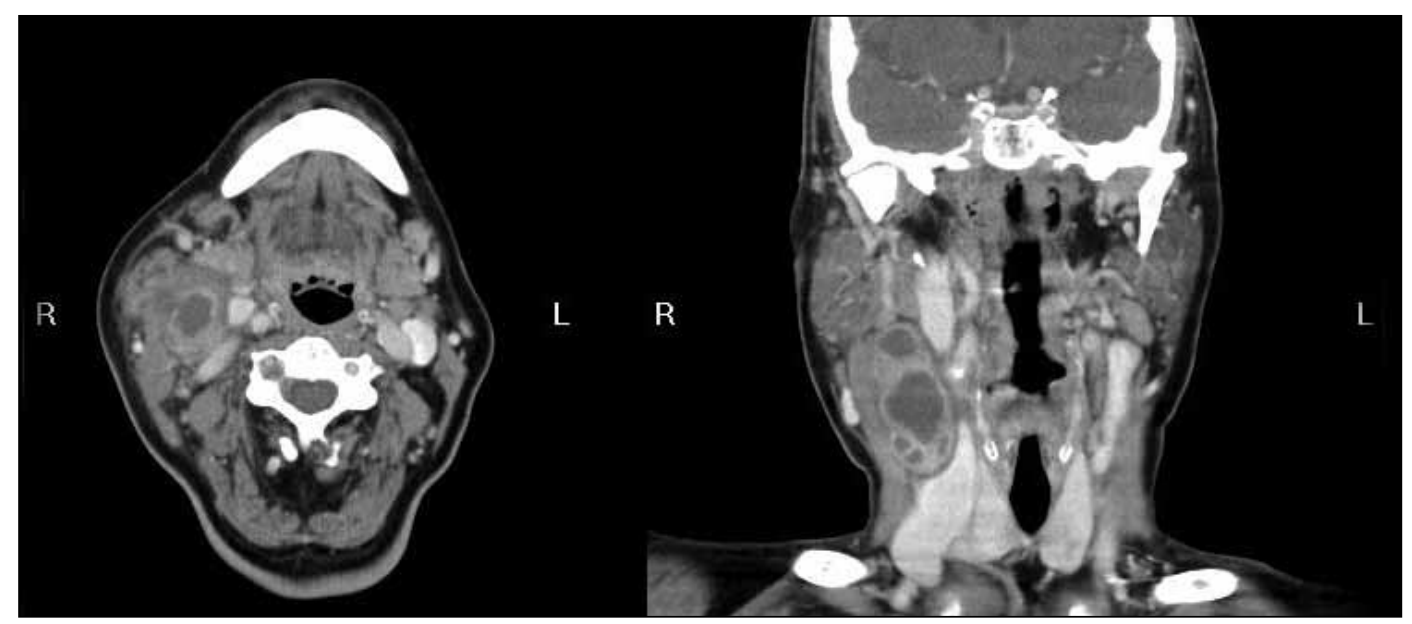

Figure 1: Mass lesion at the right neck region on axial section neck Computed Tomography (Castleman's Disease).

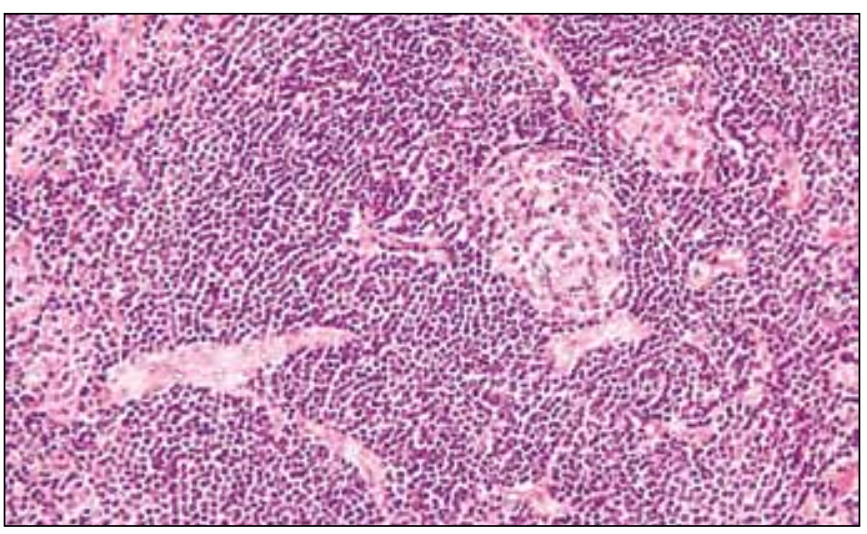

Figure 2: A germinal center and vascular proliferation that are the typical histopathological findings of Castleman's disease (H\&E, $\mathrm{x} 200)$.

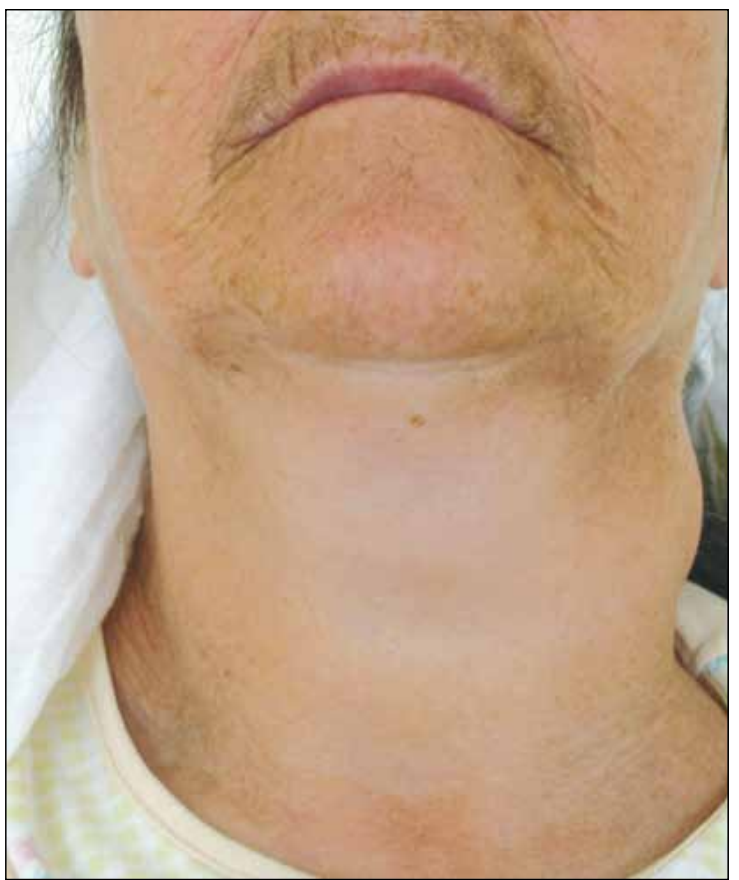

Figure 3: Case with renal cell carcinoma metastasis.

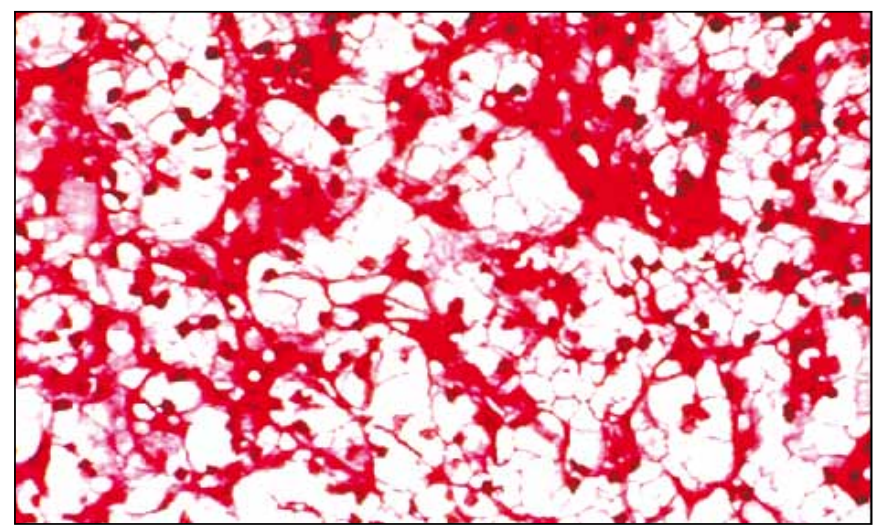

Figure 4: Histopathological appearance of renal cell carcinoma metastasis case (H\&E, $\mathrm{x} 400)$.

other local and systemic symptoms besides those belonging to the neck mass must also be investigated. The patient's own history and family history are of vital importance in the differential diagnosis (6).

The mass size, growth rate, mobility, caloric status and sensitivity are also criteria that should be evaluated in the differential diagnosis. The mass may appear suddenly in many patients, and is frequently painful and sometimes accompanied by some redness. These signs should indicate an infection more than a neoplastic process. A simple physical examination and full blood count instead of immediate advanced investigations can be sufficient to determine the origin of the infection. The patient is given antibiotic treatment in such cases. An incisional or excisional biopsy may be required if there is no resolution of the mass despite antibiotic treatment (7-9).

Diagnostic tests play an important role in differential diagnosis of neck masses. The physical examination indicates the diagnostic methods to use. For example, 
ultrasonography and Doppler would be important for a pulsating mass or one with a murmur, indicating a vascular lesion. The differential diagnosis of congenital cystic neck masses may require ancillary diagnostic methods such as ultrasonography, salivary gland lesions may require sialography and ultrasonography, inflammatory masses may require fine needle aspiration cytology and incisional and excisional biopsies while neoplastic formations or determining the relationship of masses with surrounding tissues may require CT and MR. The definite diagnosis is always by the pathologic evaluation of the mass $(10,11)$.

Inflammatory lesions are the most common neck masses in many studies from our country and this is supported by our own study $(8,9,12)$. Inflammatory lesions take first place among neck masses in developing countries while congenital and neoplastic masses are most common in developed countries $(1,2)$.

Neoplastic masses are the most frequent neck mass in patients aged 40 or over while inflammatory masses are the most common in children due to the high incidence of upper respiratory tract infection (7). The second most common neck mass in children are congenital masses (5). The most common congenital mass in our study was thyroglossal duct cyst (18 cases). We had 67 (33.33\%) neoplastic masses in our study and 23 (34.32\%) were malignant. The malignancy rate in neoplastic neck masses has been reported as 33-64\% and advanced age has been stated as one of the factors in this difference (1).

A neck mass is the first sign in 5\% of cancer patients. A neck mass is found at presentation in $12 \%$ of patients with head and neck cancers. It is therefore necessary to investigate the whole body if a neoplasm is suspected in elderly patients with a neck mass (2). Lee and Fernandes have reviewed the approach to neck masses and emphasized that a systematic evaluation is essential both for diagnosis and treatment (13).

Neoplastic masses are common in the elderly but can also be seen in the young population. These masses may be the local primary tumor itself or a result of distant metastases. $80 \%$ of the malignant neoplastic masses in the neck are derived from the upper airways and the gastrointestinal system $(6,7)$.

Torsiglieri et al. have evaluated 445 cases of childhood neck masses and found a $61 \%$ accuracy rate when they analyzed the preoperative preliminary diagnosis and postoperative definite diagnosis. They therefore state that all diagnostic methods need to be used before surgery (14). Our accuracy rate regarding preoperative preliminary diagnosis and postoperative definite diagnosis was also $61 \%$ (270 cases).

Age is an important factor in the differential diagnosis of neck masses. It is necessary to consider neoplasms in elderly patients and inflammatory or congenital lesions in children and young patients when confronted with a neck mass. The history, physical examination and ancillary diagnostic methods provide important information but the definite diagnosis will be with the histopathologic evaluation of the obtained mass.

\section{REFERENCES}

1. Batsakis JG: Tumors of the Head and Neck: Clinical and Pathological Considerations. 2nd ed, Baltimore, London, Williams and Wilcons, 1999

2. McGuirt WF: Differential Diagnosis of Neck Masses. In: Cummings CW, Flint PW, Harker LA, Haughey BH, Richardson MA, Robbins KT, et al (Eds): Cummings Otolaryngology; Head and Neck Surgery. Vol. 3, 4th ed, Philadelphia, Elsevier Mosby, 2004, 2540-2553

3. Yalçın S: Boyun Kitleleri. Çelik O. (ed), Kulak Burun Boğaz Hastalıkları ve Baş Boyun Cerrahisi. İstanbul, Turgut Yayıncılık, 2002, 4: 860-889

4. Amedee RG, Dhurandhar NR: Fine-needle aspiration biopsy. Laryngoscope 2001, 111:1551-1557

5. Gujar S, Gandhi D, Mukherji SK: Pediatric head and neck masses.Top Magn Reson Imaging 2004, 15: 95-101

6. Vowles RH, Ghiacy S, Jefferis AF: A clinic for the rapid processing of patients with neck masses. J Laryngol Otol 1998, 112:1061-1064

7. Bhattacharyya $\mathrm{N}$ : Predictive factors for neoplasia and malignancy in a neck mass. Arch Otolaryngol Head Neck Surg 1999, 125: 303-307

8. Yıldırım M, Oktay MF, Topçu İ, Meriç F: Boyun kitleleri: 420 olgunun retrospektif analizi. Dicle Tip Derg 2006, 33:210-214

9. Kasapoğlu F: Neoplastik boyun kitleleri. Türkiye Klinikleri J Surg Med Sci 2006, 2:32-39

10. Koçer N: Radyolojik bir bulgu olarak boyun kitlesi: Boyun kitlesi olan bir hastanın radyolojik incelemesinde dikkat edilecek noktalar: Hangi görüntüleme, ne zaman, nasıl? Türkiye Klinikleri J Surg Med Sci 2006, 2:10-13

11. Saraydaroğlu Ö: Boyun kitlelerinde patolojik/sitolojik tanı yöntemleri: Hangi inceleme, ne zaman, nasıl? Türkiye Klinikleri J Surg Med Sci 2006, 2:20-22

12. Uysal İÖ, Altuntaş EE, Güler C, Tuncer E: Kliniğimizde 19 yıllık periodda takipleri yapılan boyun kitleli olguların epidemiyolojik verilerinin retrospektif analizi. KBB-Forum 2010, 9:30-34

13. Lee J, Fernandes R: Neck masses: evaluation and diagnostic approach. Oral Maxillofac Surg Clin North Am 2008, 20: 321-337

14. Torsiglieri AJ Jr, Tom LW, Ross AJ 3rd, Wetmore RF, Handler SD, Potsic WP: Pediatric neck masses: guidelines for evaluation. Int J Pediatr Otorhinolaryngol 1998, 16:199-210 